\title{
FAMILY FUNCTIONING OF PEOPLE WITH SPINAL CORD INJURY
}

\author{
Kamila Santos Trierveiler ${ }^{1}$, Flavia Regina de Souza Ramos², Soraia Dornelles Schoeller ${ }^{3}$, Giovani Cavalheiro \\ Nogueira ${ }^{4}$, Maria Manuela Ferreira Pereira da Silva Martins ${ }^{5}$, Dulcinéia Ghizoni Schneider ${ }^{6}$
}

\footnotetext{
${ }^{1}$ Nurse. Florianópolis, Santa Catarina, Brazil. E-mail: kamila_st@hotmail.com

${ }^{2}$ Ph.D. in Philosophy and Health \& Nursing. Professor at the Departamento de Enfermagem and Pós-graduação em Enfermagem (PEN), Federal University of Santa Catarina (UFSC). Florianópolis, Santa Catarina, Brazil. E-mail: flavia.ramos@ufsc.br

${ }^{3}$ Ph.D. in Philosophy and Health \& Nursing. Professor at the Departamento de Enfermagem and PEN/UFSC. Florianópolis, Santa Catarina, Brazil. E-mail: soraia.dornelles@ufsc.br

${ }^{4}$ Master's in Nursing. Professor at the Instituto Federal de Educação. Florianópolis, Santa Catarina, Brazil. E-mail: giovani@ifsc.edu.br

${ }^{5}$ Ph.D. in Nursing Sciences. Dean at Superior Escola Superior de Enfermagem do Porto. Porto, Portugal. E-mail: mmartins@ esenf.pt

${ }^{6}$ Ph.D. in Philosophy and Health \& Nursing. Professor at the Departamento de Enfermagem, UFSC. Florianópolis, Santa Catarina, Brazil. E-mail: dulcineia.schneider@ufsc.br
}

\begin{abstract}
Spinal cord injury results in sensory and motor limitations and makes people dependent on their families, interfering with their autonomy and independence. This was a cross-sectional, quantitative study conducted to identify cohesion, adaptability, flexibility and family functioning of people with spinal cord injury in three cities of Florianópolis, using the family APGAR and Olson scales. The sample consisted of 45 people belonging to the age group of $14-82$ years, $64.5 \%$ male and $35.5 \%$ female; $67.7 \%$ with female caregivers and, of these, $32.2 \%$ were mothers. Despite the difficulties encountered with the injury, most families showed good functioning $(61.4 \%)$ with $16.1 \%$ to $22.5 \%$ severe and mild dysfunction, with balanced cohesion and flexibility, which were not related to the presence of low satisfaction and communication. The selected tools, applied together, proved suitable.
\end{abstract}

DESCRIPTORS: Spinal cord. Family relations. Family nursing

\section{FUNCIONALIDADE FAMILIAR DA PESSOA COM LESÃO MEDULAR}

RESUMO: A lesão medular resulta em limitações sensitivas e motoras e tornam a pessoa dependente de seus familiares, interferindo em sua autonomia e independência. Estudo transversal, quantitativo com o objetivo de identificar a coesão, adaptabilidade, flexibilidade e funcionalidade familiar da pessoa com lesão medular em três municípios da Grande Florianópolis, utilizando-se as escalas de APGAR familiar e de Olson. Constituiu-se amostra com 45 pessoas, pertencentes ao grupo etário de 14 a 82 anos, sendo $64,5 \%$ do sexo masculino e 35,5\% feminino; $67,7 \%$ dos cuidadores são do sexo feminino e, destes, 32,2\% são as mães. Apesar das dificuldades enfrentadas com a lesão, a maioria das famílias apresentou boa funcionalidade $(61,4 \%)$, com $16,1 \%$ de disfunção severa e $22,5 \%$ leve, além de tipificação equilibrada quanto à coesão e a flexibilidade, que não puderam ser relacionados à presença de baixa satisfação e comunicação. Os instrumentos selecionados, aplicados de forma conjunta, mostraram-se adequados.

DESCRITORES: Medula espinhal. Relações familiars. Enfermagem familiar.

\section{FUNCIONALIDAD FAMILIAR DE LAS PERSONAS CON LESIÓN DE LA MÉDULA ESPINAL}

\begin{abstract}
RESUMEN: La lesión de la medula espinal resulta en limitaciones sensitivas y motoras, y tornan la persona dependiente de sus familiares, lo que interfiere con su autonomía e independencia. Estudio cuantitativo transversal con el objetivo de identificar a la cohesión, adaptabilidad, flexibilidad y funcionalidad familiar de las personas con lesión de la médula espinal en tres ciudades de Grande Florianópolis, utilizando las escalas de APGAR familiar y Olson. La muestra es constituida por 45 personas pertenecientes al grupo de edad de $14-82$ años, el $64,5 \%$ hombres y 35,5\% mujeres; $67,7 \%$ de los cuidadores son mujeres y, de éstos, el 32,2\% son madres. A pesar de las dificultades con la lesión, la mayoría de las familias mostraron una buena funcionalidad (61,4\%), con un 16,1\% de la disfunción severa y 22,5\% leve, y escribiendo en equilibrio sobre la cohesión y flexibilidad, que no lo hace Ellos podrían estar relacionados con la presencia de una baja satisfacción y la comunicación. Las herramientas seleccionadas aplicadas en forma conjunta, han demostrado ser adecuado.
\end{abstract}

DESCRIPTORES: Medula espinal. Relaciones familiares. Enfermería de la familia. 


\section{INTRODUCTION}

The Ministry of Health defines spinal cord injury (SCI) as any injury to the structures of the spinal canal - medullary cone and cauda equina - which causes motor, sensory, autonomic or psychoactive changes. This is manifested by paralysis or paresis of limbs, changes in muscle tone, and changes of superficial and deep reflexes, alteration or loss of different sensitivities, loss of sphincter control, sweating and body temperature control alterations, sexual dysfunction and autonomic changes. ${ }^{1}$

Law number 7853 of October 1989, which established the National Policy for the Integration of Persons with Disabilities, defined disability as the "total or partial loss or abnormality of a structure or function, of a psychological, physiological or anatomical character, with the ability to prevent the individual's performance of a specific activity considered normal for the human being" ${ }^{2}$

For the World Health Organization (WHO), disability is a complex phenomenon, and reflects the interaction between the body and social characteristics experienced by the person. It requires collective interventions to eliminate social and environmental barriers. These people have the same health needs of others, and their health status is influenced by the social context in which they live, although they are more vulnerable to developing pressure ulcers or urinary tract infections due to their disabilities. ${ }^{3}$

According to the Brazilian Institute of Geography and Statistics (IBGE) ${ }^{4}$ the Brazilian population in 2010 was $190,755,790$ people; $13,265,597$ of these had physical disabilities, accounting for $6.95 \%$ of the general population (8.51\% women and 5.33\% men). Santa Catarina had 6,248,436 inhabitants, $6.71 \%$ with motor disabilities. Of these, $5.27 \%$ were men and $8.12 \%$ women. Florianópolis had 23,410 people with motor disabilities $-6.12 \%$ of the population of 2010; in San Jose there were 12,850 - 6.1\% of the population, and in Palhoça, there were 9,874 inhabitants $-7.18 \%$ of the local population.

The SCI is the result of a traumatic event, usually caused by traffic accidents, diving, or injury by firearm or fall. The injury may be complete or incomplete. It is complete when there is no voluntary movement and / or sensation below the level of injury, and it is incomplete when such voluntary movement/sensation exists. It implies physical and sensation changes below the level of injury, including all of the body systems (vesico- urinary, intestinal, respiratory). ${ }^{5}$ Quadriplegia involves the loss of mobility and / or paralysis of all four limbs (upper and lower); and paraplegia involves only the lower limbs. ${ }^{6}$

The injury event brings important consequences, such as changes in lifestyle, concurrent with the different stages of coping, which can weaken or optimize the rehabilitation process. The post-injury life becomes a constant learning process, since the person finds himself dependent on another, in most cases a family member, who needs to develop the ability to support and assist the person with SCI. ${ }^{7}$

The person has limitations for activities which were, previously, simple and ordinary, and needs help performing activities of daily living (ADLs). The ADLs are those related to the care of the body: hygiene, dressing, physiological, elimination and feeding. The limited capacity to perform ADLs interferes with his independence. Education of both the person with SCI, as well as his family, is essential. The rehabilitation process involves the person with the injury and his family. The structured and active family contributes to the strengthening of affective relations of the person with SCI. ${ }^{8}$

The family is central to supporting the rehabilitation process of people with SCI. Adaptation is familiar, and not only of the person who suffered the injury. The family is reorganized after the event, changing habits and lifestyles and family functioning in order to face the process. ${ }^{9}$ An overprotective family can be detrimental to rehabilitation. An indicator of overprotection is the substitution of tasks or execution of duties rather than allowing the person with injury to complete these, often accompanied by infantilization of the person who needs care. ${ }^{10}$ When the difficulty of acceptance and understanding regarding the injury are observed, the family environment is turbulent and causes, in many cases, its deconstructing. Furthermore, the difficulty in accepting the evolution of the lesion disrupts and prolongs the treatment. ${ }^{11}$

Usually, the family is not included in the treatment plan by health professionals. However, the family member will be the responsible for conducting the treatment process. The attention and care occur commonly with the person with SCI, but not with his family, which contributes negatively to a faster recovery by stimulating the rehabilitation. $^{8}$

Also, this situation can influence the level of support and unity among the family, especially 
if the union is present among the members, and can strengthen ties and more stable relationships. Family unity is not affected by the degree of dependence of the person with SCI, which is replaced by his family, especially his caregiver, such as support and reference. ${ }^{11}$

The theoretical framework adopted for this study, from the relationship between family and the person with SCI previously mentioned, is based on the Olson Model..$^{12}$ This model consists of three relevant dimensions of different theories with a family approach: cohesion, flexibility, communication. Cohesion, considers the emotional connection among members of a family; flexibility, or adaptability, assesses a family's ability to change its structure of power and its rules in new situations and challenges; and communication, which is involved in the two dimensions.

This framework is complemented by the concept of family functioning, ${ }^{13}$ which aggregates: family adaptation (the use of resources within and outside the family context, with the capacity to mitigate the problems that threaten the well-being of the family in the moment of crisis); participation (in relation to decisions and responsibilities of each family member); growth/development (portraying the physical, psychological, and especially emotional maturity of the family members by mutual support and guidance), affection (considering caring and tender relationships between family members); resolution / commitment or decision (understood as a commitment to devote one's time to a family member, encouraging him physically and emotionally, by making the relationship stable).

The interest for the role and importance of the family in the rehabilitation process, the family's contribution to the recovery of people with SCI, as well as the lack of studies and Brazilian publications regarding nursing in rehabilitation, motivated this research. The study had as central question: What functionality, cohesion, adaptability and family flexibilities are identified by people with SCI in three cities of Florianópolis?

This study aims to identify the family functioning, cohesion, flexibility and adaptability of people with SCI living in three cities of Florianópolis, based on the family APGAR scale ${ }^{13}$ and Olson's scale. ${ }^{12}$

This paper is part of research supported by FAPESC, whose main objective is to evaluate the health care of the handicapped individuals of Santa Catarina (2013-2016). The specific objective is to investigate the profile of people with disabilities, under the responsibility of the PRAXIS /PEN/UFSC research group.

\section{METHOD}

This was a cross-sectional study with a quantitative approach. The sample consisted of people with disabilities living in three cities of Greater Florianópolis. The demographic census showed that $6.71 \%$ of the population of these three cities present this disability, of which $5.27 \%$ were male and $8.12 \%$ were female.

The sample size calculation that constitutes the cutoff defined a minimum sample of 397 people with physical disabilities, among which people with SCI are included. Such sampling respected the reliability criteria of $95 \%$, providing statistical significance for the research, and constitutes a reliable basis for other researchers. For the sample calculation the following formula was used: ${ }^{14}$

$$
\mathrm{n}=\mathrm{N} /\left(\mathrm{e}^{\wedge} 2^{*} \mathrm{~N}+1\right)
$$

Where: $\mathrm{n}=$ sample size; $\mathrm{N}=$ population size; $\mathrm{e}^{\wedge}$ $2=$ squared sampling error.

This sample was selected from the teams of the family health strategy (ESF), which provided information related to the coverage area and the existence of people with disabilities in the region. For this, the health centers in the cities of Florianópolis, São José and Palhoça were visited, attempting to identify with the help of community health agents (ACS), who work in the ESF, people with disabilities within the community. Data provided by the Florianopolitana Physical Disabilities Association (Associação Florianopolitana de Deficientes Físico - AFLODEF) and Santa Catarina's Rehabilitation Center (Centro Catarinense de Reabilitação - RCC) were also used. The data from these sites enabled the identification of 163 people with SCI. From the active search for these people, only 49 people were found (due to missing addresses, the absence of a deficiency, missing people), and were contacted by telephone and invited to participate. Four of them refused to participate in the interview, as they did not believe there would be benefits for themselves from the study, or because they did not want to talk about their condition. The research was conducted with 45 people with SCI living in the cities of Florianópolis, Palhoça and São José, in the state of Santa Catarina.

The study location selected for data collection was the participant's home. This was to 
provide more comfort while administering the instruments. The study was based on the National Health Council Resolution 466/12. The participants were interviewed after reading and signing the Terms of Free and Informed Consent (TFIC). Those who were unable to sign had the consent signed by their guardians. People were excluded if they had any communication or cognition disabilities or difficulties that prevented the collection of data.

Data collection was performed between the months of March to June of 2014, by the administration of instruments to characterize participants according to age, sex, religion, education, marital status, family income and the family APGAR ${ }^{13}$ and OLSON scales. ${ }^{12}$

The family APGAR scale dates from 1978, developed with five questions that analyze and evaluate the individual's perception regarding the functioning of his family. ${ }^{12}$ This scale characterizes components considered as essential for the function of the family, described in the reference of the study and cited in original terms, in the English language, forming the acronym APGAR: Adaptability (family adaptation); Partnership (participation); Growth (growth); Affection (affect); Resolve (resolution). For all five questions, only one response is allowed, which may be: almost always, sometimes, and rarely, with values of 2, 1 and 0 , respectively. At the end of the scale, the values for each question are summed. If score is 7-10, the family is considered functional; if score is 4-6, the family is seen to have a mild dysfunction; if the score is $0-3$, the family is considered to have severe dysfunction. ${ }^{15}$

The Olson scale summarizes the circumflex model of Olson, which assumes that among the different levels of cohesion and adaptability (Figure 1) the more moderate or non-extreme levels are more favorable to balanced family functioning. ${ }^{16}$ Cohesion is the ability of the family to remain united, and flexibility refers to changes in rules and family leadership. ${ }^{17-18}$

Data were recorded and later sent to a GO CANVAS provider, which stores and offers in csv, format for descriptive statistical analysis. The study was approved by the Ethics Committee on Human Research of the Federal University of Santa Catarina, protocol number 216396.

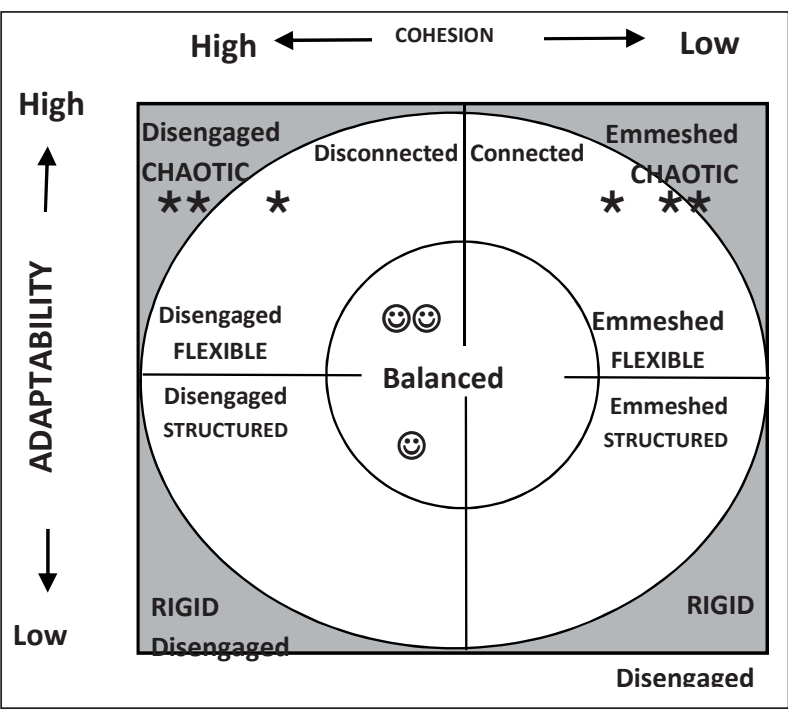

Figure 1 - Circumplex model of Olson, adapted to represent the main findings of this study ${ }^{* 12}$

\section{RESULTS}

\section{Participants' profile}

The characteristics of the study population are shown in Table 1 . The participants were within the age group of $14-82$ years old; $71.1 \%$ were male and $28.9 \%$ female. With regard to marital status, $44.4 \%$ reported being single, $34.7 \%$ married, $15.4 \%$ divorced / separated and $4.4 \%$ were in a stable relationship. As for current occupation, $46.6 \%$ were retired due to disability, $17.7 \%$ worked formally (active) and $24.4 \%$ had no occupation. Of these people, $79.5 \%$ lived with a family member, and the others $(6.6 \%)$ lived alone, in health or charity institutions, or with a paid caregiver.

Table 1 - Characteristics of the study participants. Santa Catarina, 2014

\begin{tabular}{lcc}
\hline Variable & $\mathbf{n}$ & $\%$ \\
\hline Sex $(\mathrm{n}=45)$ & 13 & 71.1 \\
$\quad$ Female & 32 & 28.9 \\
$\quad$ Male & & \\
Marital status ( $\mathrm{n}=45)$ & 20 & 44.4 \\
$\quad$ Single & 16 & 35.6 \\
$\quad$ Married & 07 & 15.6 \\
$\quad$ Divorced/Separated & 02 & 4.4 \\
$\quad$ Stable relationship & \multicolumn{3}{c}{31.1} \\
Education (n=45) & 14 & \multicolumn{2}{c}{ continua $\rightarrow$} \\
$\quad$ Incomplete elementary education & \multicolumn{3}{c}{}
\end{tabular}

* Free translation of authors from Spanish to Portuguese. 


\begin{tabular}{lcc}
\hline Variable & n & \% \\
\hline Complete elementary education & 02 & 4.4 \\
Complete high school & 01 & 2.2 \\
Complete high school & 10 & 22.2 \\
Incomplete higher education & 12 & 26.8 \\
Complete higher education & 06 & 13.3 \\
Occupation (n=45) & & \\
Retired due to disability & 22 & 48.9 \\
No occupation & 09 & 20.0 \\
Active/working & 08 & 17.8 \\
Benefits due to disability & 06 & 13.3 \\
Living with: (n=44) & & \\
Family & 24 & 54.5 \\
Wife/husband & 11 & 25.0 \\
Alone & 03 & 6.8 \\
Health institution & 01 & 2.3 \\
Charity institution & 01 & 2.3 \\
Nursing professional & 01 & 2.3 \\
Caregiver & 01 & 2.3 \\
Others & 02 & 4.5 \\
& & \\
& continua $\rightarrow$
\end{tabular}

Among the 45 participants, $31.1 \%$ did not finish elementary education, $26.8 \%$ did not complete higher education, $22.2 \%$ completed high school, $26.8 \%$ had an undergraduate degree, $4.4 \%$ completed elementary school, and 2.2\% completed high school; $75.5 \%$ had their own homes, $17.8 \%$ lived in a rented house, and $6.7 \%$ in a courtesy residence. Only $20 \%$ practiced any physical activity.

\begin{tabular}{lcc}
\hline Variable & $\mathbf{n}$ & \% \\
\hline Residence $(\mathrm{n}=45)$ & 34 & 75.5 \\
Own & 08 & 17.8 \\
Rent & 03 & 6.7 \\
Courtesy & & \\
Family income in minimum wage & & \\
(n=45) & 16 & 35.6 \\
$<2$ & 19 & 42.2 \\
$2-4$ & 04 & 8.9 \\
$5-7$ & - & - \\
$8-10$ & 06 & 13.3 \\
$>10$ & & \\
Physical activity (n=45) & 36 & 80.0 \\
Does not practice & 03 & 6.8 \\
Rugby + academy & 02 & 4.4 \\
Physiotherapy & 01 & 2.2 \\
Weight training & 01 & 2.2 \\
Orthostatism + weight training & 01 & 2.2 \\
Push ups & 01 & 2.2 \\
Basketball & \multicolumn{2}{c}{ conclusão } \\
& &
\end{tabular}

According to Table 2, 51.1\% have paraplegia, followed by quadriplegia (26.7\%) and hemiplegia and hemiparesis, both with $8.9 \%$ each. Those with paraparesis and tetraparesis, represent $2.2 \%$ of the cases. The most frequent cause was car accident (26.7\%), followed by motorcycle accident in $24.4 \%$, and injuries by knives and falls, both with $11.1 \%$. The occurrence of $8.9 \%$ cases of running over, with equal representation of the injury caused by diving and $6.7 \%$ of cases of SCI for surgical error.

Table 2 - People with spinal cord injury according level and cause of injury $(n=45)$. Santa Catarina, 2014

\begin{tabular}{lcccccccc}
\hline Level & $\begin{array}{c}\text { Car } \\
\text { accident }\end{array}$ & $\begin{array}{c}\text { Motorcycle } \\
\text { accident }\end{array}$ & Fall & $\begin{array}{c}\text { Injury by } \\
\text { knives }\end{array}$ & $\begin{array}{c}\text { Running } \\
\text { over }\end{array}$ & Diving & $\begin{array}{c}\text { Surgery } \\
\text { error }\end{array}$ & Other \\
\hline Tetraplegia & 3 & 3 & - & 1 & 1 & 2 & 2 & - \\
Paraplegia & 4 & 8 & 2 & 4 & 2 & 1 & 1 & 1 \\
Hemiplegia & 2 & - & 1 & - & 1 & - & - & - \\
Tetraparesia & 1 & - & - & - & - & - & - & - \\
Paraparesis & - & - & - & - & - & 1 & - & - \\
Hemiparesis & 2 & - & 2 & - & - & - & - & - \\
\hline Total & $\mathbf{1 2}$ & $\mathbf{1 1}$ & $\mathbf{5}$ & $\mathbf{5}$ & $\mathbf{4}$ & $\mathbf{4}$ & $\mathbf{3}$ & $\mathbf{1}$ \\
\hline
\end{tabular}

Table 3 shows the prevalence of mothers and wives as the primary caregivers of people with SCI. Among female caregivers, $31.8 \%$ were wives, $27.2 \%$ were mothers, $13.6 \%$, were health care work- ers, represented by nursing technicians, and in $2.2 \%$ of cases, the caregiver was the grandmother; $22.58 \%$ did not require a caregiver. 
Table 3 - Sex and primary caregiver of the person with spinal cord injury $(n=45)$. Santa Catarina, 2014

\begin{tabular}{lccccc}
\hline \multirow{2}{*}{$\begin{array}{l}\text { Person with spinal cord } \\
\text { injury (sex) }\end{array}$} & Mother & Husband/Wife & Other parent & Professional & Self care \\
\cline { 2 - 6 } Male (32) & 10 & 13 & 2 & 2 & 5 \\
Female(13) & 2 & 1 & 1 & 4 & 5 \\
\hline Total & $\mathbf{1 2}$ & $\mathbf{1 4}$ & $\mathbf{3}$ & $\mathbf{6}$ & $\mathbf{1 0}$ \\
\hline
\end{tabular}

Comparatively, women with SCI express a greater ability for self-care $(38.5 \%$ reported self-care), as opposed to $15.6 \%$ of men. Also, when considering mothers and wives as primary caregivers, the number of men who have such caregivers is much higher $(71.9 \%)$, compared to only $23 \%$ of women.

\section{Family APGAR scale}

Among the 45 participants, $11.1 \%$ answered that their families had a severe dysfunction, $22.5 \%$ had mild family dysfunction, and $66.7 \%$ considered their families functional (Table 4).

Table 4 - APGAR scale of the families of the person with spinal cord injury $(n=45)$. Santa Catarina, 2014

\begin{tabular}{lrr}
\hline Family functioning & $\mathbf{n}$ & \% \\
\hline Highly functional & 30 & 66.7 \\
Mildly dysfunctional & 10 & 22.2 \\
Severely dysfunctional & 5 & 11.1 \\
\hline Total & $\mathbf{4 5}$ & $\mathbf{1 0 0}$ \\
\hline
\end{tabular}

\section{Olson Scale}

According to the data in Table 5, 61.28\% reported low or very low family satisfaction, and 17.4 reported high or very high satisfaction; 45.15 referred to low or very low communication. As for adaptability, $67.74 \%$ considered their families to be a little rigid and $96.77 \%$ a little chaotic. As for cohesion, $96.77 \%$ recognized their families as a little enmeshed, and $80.64 \%$ a little disengaged. The extreme levels were less expressive, very low adherence (disengaged), or very high adherence (enmeshed). Most fell within balanced levels of separation (low / moderate cohesion) and connection (cohesion moderate / high).

Table 5 - Olson scale of people with spinal cord injury. Santa Catarina, 2014.

\begin{tabular}{lccccc}
\hline Items & $\begin{array}{c}\text { Very high } \\
\text { \% }\end{array}$ & $\begin{array}{c}\text { High } \\
\%\end{array}$ & $\begin{array}{c}\text { Moderate } \\
\%\end{array}$ & $\begin{array}{c}\text { Low } \\
\%\end{array}$ & $\begin{array}{c}\text { Very Low } \\
\%\end{array}$ \\
\hline Satisfaction & 12.90 & 6.45 & 19.35 & 25.80 & 35.48 \\
Communication & 9.67 & 9.67 & 35.48 & 19.35 & 25.80 \\
Rigid & & & 32.25 & 45.16 & 22.58 \\
Chaotic & & 3.22 & 35.48 & 61.29 \\
Enmeshed & & 3.22 & 45.16 & 51.61 \\
Disengaged & 3.22 & 16.12 & 35.48 & 45.16 \\
\hline
\end{tabular}

Table 6 shows the cohesion and flexibility of families. 
Table 6 - Olson scale of people with spinal cord injury, cohesion and flexibility. Santa Catarina, 2014

\begin{tabular}{lll}
\hline Connected/flexible & Cohesion & Flexibility \\
\hline Much & $25.80 \%$ & $41.93 \%$ \\
Little & $45.16 \%$ & $16.12 \%$ \\
\hline
\end{tabular}

\section{DISCUSSION}

This study found out that young men become paraplegic due to traffic accidents (cars and motorcycles). These findings are similar to other studies ${ }^{19-21}$ that found young men become paraplegic due to traffic accidents (cars and motorcycles). The injuries mostly affect young, economically active adults. Their lifestyle often combines alcohol, drugs and driving, which can contribute to increasing the number of victims of SCI. ${ }^{22}$

The prevalence of female caregivers, notably mothers, refers to the importance of the family in the post-injury process, which shows a resemblance to situations of chronic dependence, such as in the case of the elderly. This finding is consistent with another study ${ }^{23}$ in which $87.5 \%$ of caregivers were female, with a predominance of married, adult women with low education.

In another study, out of 100 elderly respondents, 92\% reported that their caregivers were women, $62 \%$ were their sons/daughters, $4 \%$ grandsons/granddaughters, $7 \%$ spouses, and $26 \%$ others, such as daughter-in-law, neighbors, friends, nieces, housekeepers or hired caregivers. These data reflect the Brazilian cultural pattern that assigns the role of primary caregiver as a female function. The low educational level of the female caregivers hinders the health education process. More resources and dynamics are necessary for the health professional to achieve his goals with the caregivers. ${ }^{22}$

Compared with women with SCI, men with SCI expressed greater dependence on the care of others. Although no differences were found regarding the type of injury, the number of women who perform self-care is inversely proportional to the number of men and those with caregivers who are mothers or spouses are three times lower than that of men who are cared for by their mothers and wives. This fact should be further developed in new research, because it also affects the very notion of the caregiver to whom these people refer.

As for family functioning, $61.4 \%$ of respondents reported having good family function, 22.5\% had mild dysfunction, whereas $16.1 \%$ had severe family dysfunction. There were similarities regarding results of other studies with reduced severe dysfunction and some cases of mild dysfunction. One study with 12 chronic patients from Maringá considered four families as functional, five families as slightly dysfunctional and three families as severely dysfunctional. ${ }^{24}$ Another study of 117 dependent elderly in Bahia had 32 functional families, 54 families with mild dysfunction, whereas 31 have severe family dysfunction. ${ }^{25}$ In a study performed in Braga/Portugal ${ }^{26}$ with 85 children with chronic diseases, $81 \%$ had good family functioning, $14 \%$ considered their family as slightly dysfunctional and 4\% considered their family as severely dysfunctional. This was a result with better functional assessments, perhaps because the care and attention were directed to the children.

The family as well as health care professionals, plays an active role in the rehabilitation process of the person with SCI, able to provide support and encouragement in addressing his condition and his desire to live as harmoniously as possible with the injury and the limitations that it causes. The family is essential in the rehabilitation of the person; motor impairment affects not just the person with $\mathrm{SCI}$, but the family that lives with him. ${ }^{8}$ Most respondents considered their families to be not very enmeshed/ engaged. In Figure 1, the model area where the answers concentrated are marked with the symbol («), showing that families are considered disengaged or disconnected (in a range that goes from extremely disengaged, going through separation, connected, to enmeshed, at the other end). However there is a contradiction with the result that expresses those who also consider themselves very little or poorly disengaged $(90.6 \%)$, thereby suggesting a conflict between these results (which is emphasized in the opposite areas of the model on the horizontal line between high and low cohesion).

With regard to adaptability, the families were considered to have low to moderate rigidity, thereby totaling $77.4 \%$ among the intermediate levels (central circles in the model) marked with the symbol (J), since the more central, the higher the balance. The other end of adaptation, which is the chaotic family, was also considered very low or low, totaling $67.7 \%$, which demonstrates consistency with the result of low rigidity and low chaos, namely higher balance among areas that indicate flexible and structured families.

In relation to satisfaction, the majority of respondents reported having low or very low 
satisfaction $(61.3 \%)$, whereas $80.6 \%$ portray inefficient communication among family members, considering the very low, low and moderate levels of communication. The relationship between communication and satisfaction should be further studied, but a possible relationship is indicated in which the lower the communication, the lower the satisfaction.

In the pre-rehabilitation phase there is a different planning of strategies among people with SCI and their families, whereas in the post-rehabilitation phase there is a greater quest for independence. Rehabilitation aims at working with the coping modes of people with SCI, mobilizing them in the search for actions that can contribute to better adaptation. Rehabilitation requires clarity of information and dissemination, considering the social and family context in order to improve quality of life. ${ }^{8}$

The family refers above all to shared experiences that are full of meanings. The family is based on the construction of identity and the person with the SCI becomes the most important in life, especially in higher dependency situations. The consequences of SCI make the caregiver, usually a family member, interfere with routine interactions and family dynamic. ${ }^{11}$

In the process of adaptation of the person with SCI, all family members are important, although some are individualized, making the family support concentrated. Although people with SCI fight to conquer dependence, the family often goes against this desire by acting protectively, which will result in the hinderance of the rehabilitation process. The aid of family members in the performance of daily activities is important, but they should not be performed only by the family or caregiver, but should be distributed to all, including the person with disability. The approach should aim to be a permanent stimulus for independence. ${ }^{10}$

This situation can influence the level of support in the family. In particular, if there is union among the members, it can strengthen ties and establish more stable relationships. This union is not affected by the degree of dependence of the person with SCI, who has her family, especially her caregiver, as a support and reference..$^{12}$ Autonomy is seen as an individual freedom in which people have the right to express themselves and take care of their most intimate and fragile side. In order to do this, the person must master her own care, and if this is not possible, another person takes charge of care, usually a family member. ${ }^{27}$
Nurses are supposed to construct knowledge about the care of people with SCI, the complexity of the commitment and bodily functions, and the high degree of dependence. ${ }^{27}$ They can contribute to care, and instruction on family care, interacting with people with SCI, their families and caregivers. It is important to identify which ADLs and self-care abilities are compromised. ${ }^{27}$

The way relationships and adaptations are developed characterize the family system as functional or dysfunctional. The system is functional when the family experiences conflicts and situations appropriately and with emotional balance, and it is possible to harmonize their own function in relation to others emotionally, maintaining the integrity of the family system and individual autonomy. In a dysfunctional system there is no harmony and cooperation among the family members. ${ }^{24}$

Family function is important, given that the satisfaction of the caregiver and the person under care is proportional to the quality of care. Thus, in accordance with the model, the dimension of cohesion (Figure 1) has the following levels: disengaged (extremely low cohesion); disconnected (low / moderate cohesion); connected (moderate/ high cohesion) and enmeshed (extremely high cohesion). ${ }^{17}$

Thus, in the levels considered balanced (separate and linked), there is greater functioning among family members, with people being able to oscillate among the other levels, in family crisis situations (e.g. transitions in the life cycle). However, this is not true in the most extreme levels (disengaged and enmeshed), considered to be umbalanced. ${ }^{28}$

In the balanced levels, a family with a disengaged relationship indicates some emotional separation (but not extreme), time spent without the family is considered important, unlike a connected relationship, in which more importance is attributed to the time spent with family, because there is greater emotional closeness and loyalty among members. In extreme levels, a disconnected relationship is characterized by an emotional separation and poor engagement among family members.

\section{CONCLUSION}

The use and application of the family APGAR scale evaluated the importance of family presence after SCI. This situation demands re- 
structuring of family dynamics. In addition, the experience is variable in each family.

Although most of the individuals interviewed reported good family functioning, dissatisfaction in relation to the family was perceptible, which suggested a relationship with the result of poor communication among its members. Despite this dissatisfaction, extreme rigidity and family chaos were not significant, thereby showing a balanced classification between structured and flexible. Likewise, the families were placed in a balanced way as to cohesion in separation and connection levels, but without extremes (disengaged or enmeshed).

Despite the difficulties with the injury, there was cohesion between the family and the person with SCI, as well as good flexibility, with low rigidity in their relationships. There was a contradiction with the results of low satisfaction and communication, suggesting the need to develop more studies, especially considering the lack of research in the area, or use the family APGAR related to the SCI scale.

The assessment of family function and family relationship, and how the person with SCI deals with them, are important to establish a better therapeutic plan and rehabilitation process that is able to provide the person with a better quality of life.

The objectives of this study were met by discussing the family function of 45 people with SCI in three cities in Grande Florianópolis, identifying family cohesion, flexibility and adaptability of these participants, by adopting the family APGAR and Olson scales, respectively.

This study is limited by the lack of investigations with people with SCI, which makes it difficult to compare the variables discussed among the various populations. It is expected to contribute to the advancement of knowledge on the subject.

\section{REFERENCES}

1. Ministério da Saúde (BR). Secretaria de Atenção à Saúde. Departamento de Ações Programáticas Estratégicas. Diretrizes de atenção à pessoa com lesão medular [Internet]. Brasília (DF): MS, 2013. [acesso 2013 nov 21]. Disponível em: http:/ / bvsms. saude.gov.br/bvs/publicacoes/diretrizes_atencao_ pessoa_lesao_medular.pdf

2. Brasil. Lei no 7.853, de 24 de outubro de 1989. Dispõe sobre o apoio às pessoas portadoras de deficiência, sua integração social, sobre a Coordenadoria Nacional para Integração da Pessoa Portadora de Deficiência - Corde, institui a tutela jurisdicional de interesses coletivos ou difusos dessas pessoas, disciplina a atuação do Ministério Público, define crimes, e dá outras providências. Diário Oficial da República Federativa do Brasil, 25 Out 1989.

3. Organização Mundial da Saúde. Health topics. Disabilities [Internet]. [acesso 2013 nov 22]. Disponível em: http://www.who.int/topics/ disabilities/en/

4. Instituto Brasileiro de Geografia e Estatística [Internet]. Censo Demográfico 2010. Estados. Santa Catarina. [acesso 2014 jun 24]. Disponível em: http://www.ibge.gov.br/estadosat/perfil. php?sigla $=$ sc

5. Rede Sara de Hospitais de Reabilitação [online]. Lesão Medular. [acesso $2013 \mathrm{dez}$ 1]. Disponível em: http://www.sarah.br/Cvisual/Sarah/AADoencas/po/p_08_lesao_medular.html

6. Vasconcelos ECLM, Riberto M. Caracterização clínica e das situações de fratura da coluna vertebral no município de ribeirão preto, propostas para um programa de prevenção do trauma raquimedular. Coluna/Columna [Internet]. 2011, 10(1):4043. Disponível em: http://dx.doi.org/10.1590/S180818512011000100007

7. Ferreira M, Marina Prista GM. Adaptação à lesão vertebro-medular. Sociedade Portuguesa de Psicologia da Saúde. Psicol Saúde Doenças [Internet]. 2014 [acesso 2014 jan 17]; 15(2):380-95. Disponível em: http://dx.doi.org/10.15309/14psd150205

8. Schoeller SD, Bitencourt RN, Leopardi MT, Pires DP, Zanini MTB. Mudanças na vida das pessoas com lesão medular adquirida.Rev Eletr Enferm. [Internet]. 2012 [acesso 2013 nov 24]; 14(1): 95-103. Disponível em: http://www.fen.ufg.br/revista/ v14/n1/pdf/v14n1a11.pdf

9. Silva DGV, Treintini M, Meirelles BHS, Bonetti A, Souza SS, Dornelles S. Estresse e enfrentamento de pessoas em condição crônica. Programa de Atualização, 2011. 6: 35-70.

10. Henriques F. Paraplegia: percursos de adaptação e qualidade de vida. Coimbra (PT): Formasau Formação e Saúde, Lda; 2004.

11. Lemos ND. O papel da família no tratamento do paciente com AVC: a intervenção do serviço social. In: Gazzola JM, Bofi TC, Carvalho AC. Pós acidente vascular cerebral: orientação domiciliária. São Paulo: Livraria Santos Editora; 2007. p. 27-31.

12. Martínez-Pamplegia A, Iraugi I, Galíndez E, Sanz M. Family Adaptability and Cohesion Evaluation Scales (FACES): desarrollo de la una versión de 20 ítems em español. Inter J Clinic Health Psychol [Internet]. 2006 [acesso 2014 jun 14]. 6(2):317-38. Disponível em: http:/ / www.redalyc.org/articulo.oa?id=33760207 
Trierveiler KS, Ramos FRS, Schoeller SD, Nogueira GC, Martins MMFPS, Schneider DG

13. Pedreira LC, Oliveira AMS. Cuidadores de idosos dependentes no domicílio: mudanças nas relações familiares. Rev Bras Enferm [Internet]. 2012 [acesso 2014 jan 17]; 65(5):1-10. Disponível em: http:/ / www.scielo.br/scielo.php? script $=$ sci $_{-}$ arttext\&pid=S0034-71672012000500003

14. Barbetta PA. Estatística aplicada às ciências sociais. Florianópolis (SC): Ed. UFSC; 2007. 7: 315.

15. Andrade AINPA, Martins RML. Funcionalidade familiar e qualidade de vida dos idosos. Milenium [Internet]. 2011 [acesso $2013 \mathrm{dez} 1$ ]; 40:185-99. Disponivel em: http://www.ipv.pt/millenium/ Millenium40/13.pdf

16. Olson DH, Gorall DM. FACES IV \& the Circumplex Model. 2006. [acesso 2014 jan 17]. Disponível em: http:/ /www.zvitoren.com/files/ FACESIVtheCircumplexModel-DOLSON2006.pdf

17. Rua MAGA. Qualidade de vida do doente após acidente vascular cerebral [dissertação]. Viseu (PT): Instituto Politécnico de Viseu, Escola Superior de Saúde de Viseu; 2012 [acesso 2013 dez 1] Disponível em:http:/ / repositorio.ipv.pt/ handle/10400.19/1659

18. Ball DC, Tornaría MJG, Masjuan N, Trápaga MA, Arca DD, Scafarelli L, et al. Escala de Evaluación del Funcionamiento Familiar - FACES IV: Proceso de adaptación a Montevideo, Uruguay. Ciênc Psicol [Internet]. 2009 [acesso 2014 mar 24]: 3(1). Disponível em: http:// www.scielo.edu.uy/scielo.php?pid=S1688-42212009000100005\&script=sci_arttext

19. Rodrigues AV, Vidal WAS, Lemes JA, Gôngora CS, Neves TC, Santos SMS, et.al. Estudo sobre as características da dor em pacientes com lesão medular. Acta Fisiátrica [Internet]. 2012 Set. [acesso 2014 jun 14]. 19:3. Disponível em: http://www. actafisiatrica.org.br/detalhe_artigo.asp?id $=473$

20. Silva GA, Schoeller SD, Gelbcke FL, Carvalho ZMF, Silva EMPJ. Avaliação funcional de pessoas com lesão medular: utilização da escala de independência funcional - MIF. Texto Contexto Enferm [Internet]. 2012 [acesso 2014 junho 14]. 4(21):929-36. Disponível em: http://www.scielo.br/pdf/tce/v21n4/25.pdf

21. Venturini DA, Decesaro MN, Marcon SS. Conhecendo a história e as condições de vida de indivíduos com lesão medular. Rev Gaúcha Enferm [Internet]. 2006. [acesso 2014 jun 14]. 2(27):219-29. Disponível em: http://seer.ufrgs.br/ index.php/RevistaGauchadeEnfermagem/article/ view/4600/2520

22. Santos AA, Pavarini SCI. Funcionalidade familiar de idosos com alterações cognitivas: a percepção do cuidador. Rev Esc Enferm USP [Internet]. 2012. [acesso 2014 jun 14]. 46(5):1141-7. Disponível em: http://www.scielo.br/pdf/reeusp/v46n5/15.pdf

23. Gonçalves LHT, Nassar SM, Daussy MFS, Santos SMA, Alvarez AM. O convívio familiar do idoso na quarta idade e seu cuidador. Ciência Cuidado Saúde [Internet]. 2011 [acesso 2014 jun 14]; 10(4):74654. Disponível em: http:// periodicos.uem.br/ojs/ index.php/CiencCuidSaude/article/view/18319/ pdf

24. Santos AL, Cecílio HPM, Teston EF, Marcon SS Conhecendo a funcionalidade familiar sob a ótica do doente crônico. Texto Contexto Enferm [Internet], 2012. [acesso 2014 mai 24]. 21(4):879-86. Disponível em: http://www.scielo.br/pdf/tce/v21n4/19.pdf

25. Torres GV, Reis LA, Reis LA, Fernandes MH. Qualidade de vida e fatores associados em idosos dependentes em uma cidade do interior do Nordeste. J Bras Psiquiatr [Internet] 2009. [acesso 2014 junho 08]. 58(1): 39-44. Disponível em: http:/ / www.scielo.br/pdf/jbpsiq/v58n1/a06v58n1.pdf

26. Oliveira C, Araújo B, Rodrigues V. Famílias de crianças com doença crónica: percepção de coesão familiar. In: Carvalho JC, editor. Transferibilidade do conhecimento em enfermagem de família. Porto (PT): ESEP; 2012. p.147-51.

27. Machado WCA, Scramin AP. (In)dependência funcional na dependente relação de homens tetraplégicos com seus (in)substituíveis pais/ cuidadores. Rev Esc Enferm USP [Internet]. 2010. [acesso 2014 mai 24]. 44(1):53-60. Disponível em: http://www.scielo.br/pdf/reeusp/v44n1/ a08v44n1.pdf

28. Machado MME. Aliança parental, Coesão e Adaptabilidade familiar ao longo do ciclo vital da família [dissertação]. Lisboa (PT): Universidade de Lisboa; 2008. 